\title{
A Study on Financial Distress in Indian Steel Industry under Globalization
}

\author{
Shrabanti Pal \\ Assistant Professor, Department of Commerce, JD Birla Institute \\ Main Campus 11, Lower Rawdon Street \\ Kolkata-700020
}

\begin{abstract}
The present study was an attempt to determine the financially healthy and weak steel companies in India to assess overall industrial condition by applying discriminant analysis for the study period of twenty years since 1991-92 to 2010-11. The study was conducted on ten Indian steel companies whose market share was more than 77 percent in 2009-10. Initially the study as started with eight financial ratios selected from different areas like profitability, liquidity, solvency and efficiency. A strong discriminant function was developed with three ratios found to be significant in discriminating power and classification results. Profitability and efficiency ratios such as return on investment, debtor turnover ratio and fixed assets turnover ratio are most important indicator to distinguish between financially healthy and financially weak companies. Hence, to become financially healthy the steel companies must try to improve return on investment by applying proper debtor and fixed assets management policy in Indian context.
\end{abstract}

Key words: Indian steel industry; Discriminant analysis; Financial distress in Indian steel industry, Overall financial health of Indian steel industry

\section{Introduction}

Financial statement analysis is one of the most important analytical techniques to describe the financial strength and weakness as well as overall financial health of the companies. It helps to describe the trend and changes in the financial performance of the companies over the periods. It is usually recognized that the aim of financial statements is to offer information about the financial position, performance and changes in financial position of a company which become very effective for the users in making economic decision (Deloitte, 2007). Financial distress refers to a situation where a company cannot pay or faces difficulties to pay off its obligations to creditors. If a company suffers from such situation for a long time it has every possibility to become bankrupt in near future. To determine the financial distress discriminant analysis can be applied. Discriminant analysis is one of the most reliable statistical tools to determine the financial distress of the industry. The present study aims at determining the financial distress of Indian steel industry for a period of twenty years since 1992 to 2011.

\section{Review Of Literature}

Linear discriminant analysis is a time-bound standard tool for classification. Altman (1968) developed a model for the prediction of corporate bankruptcy using the sample 66 publicly traded manufacturing firms out of which 33 bankrupt and 33 non-bankrupt matching firms for a period of 20 years ranging from 1946 to 1965. Ohlson (1980) conducted a study on 105 bankrupt firms and 2058 non-bankrupt firms considering data for a period of 7 years since 1970 to 1976 to predict the corporate failure by applying multiple discriminant analysis and identified four basic factors (measures of financial structure, size of the company, measures of performance and measures of current liabilities) which had significant contribution in affecting the probability of failure. Ramanujam, Venkatraman, and Camillus (1986) employed discriminant analysis in their study to evaluate the ability of key dimensions of planning system to make the distinction between more and less effective planning systems using three different criteria of planning effectiveness. Back (1996) conducted a research to choose bankruptcy predictors by applying discriminant analysis, logit analysis and genetic algorithms on a sample of 37 matched pair of companies. He used 31 financial ratios to make the accurate prediction of business failure. Dichev (1998) applied z-score model and Ohlson conditional Logit model to examine the relation between bankruptcy risk and systematic risk and found that bankruptcy risk is not rewarded by higher return. Shirata (1998) applied multiple discriminant analysis on a sample of total 986 Japanese firms (686 bankrupt firms and 300 non-bankrupt firms) in his study to predict Japanese corporate bankruptcy and developed a linear discriminant function in this regard. His study also indicated that the Japanese bankrupt firms had indicated their worse financial position for a considerable time before they went bankrupt. Cleary (1999) applied discriminant analysis to determine the financial status of 1317 US firms and classify the firms according to financial variables that are related to financial constraints for a period of 7 years started from 1988 to 1994. The study captured 
desired cross sectional properties of a large number of firms and successfully classified the firms that increase or decrease the dividends 74 percent of the time. Dimitras, et al. (1999) applied discriminant analysis in their study on a large sample of 80 Greek firms to discriminate financially healthy and bankrupt firms for prediction of business failure. Lenmox (1999) carried on a study on 949 UK listed companies for a period of 7 years ranging from 1987 to 1994 and applied discriminant analysis in his study to identify the most important determinants of bankruptcy. His study demonstrated that the industry sector, company size and the economic cycle have important effects on the likelihood of corporate failure, which is expected to increase when the company in question is unprofitable, is highly leveraged and it has liquidity problems. Charitou et al. (2004) conducted a study on 51 matched pair of UK public industrial firms for a period of 10 years ranges between 1988 and 1997 to predict the financial distress and thus applied discriminant analysis to develop a reliable business failure prediction model. The above model can be used to assist investors, creditors, managers, auditors and regulatory agencies in UK to predict the probability of business failure. Bhunia and Sarkar (2011) carried on a study on 64 private pharmaceutical companies for a period of 10 years since 1996 to 2005 and applied multiple discriminant analysis on selected financial ratios from different segments like liquidity, profitability, solvency and efficiency to develop a business failure prediction model.

\section{Objective of Study}

The objective of the present study is to determine the financial distress of steel industry in India under post-liberalization period.

\section{Source of Data}

The present study is envisaged to be predominantly empirical in nature and based on secondary data. The relevant data are collected from secondary sources like CMIE database, audited balance sheets and profit and loss account, annual reports of respective companies, economic survey and annual survey of Industries.

\section{Selection of Data}

Traditionally Indian steel industry is categorized into main, major and secondary producers. The sample of companies has been chosen on the basis of their market shares for the year 2009-10. The market share of the company is computed by diving corresponding sales of the company (Rs. in Crore) by industry's total sales. The study includes a representative sample of companies having more than 1 percent of market share. The referred period of study is twenty years from 1991-92 to 2010-11. Table-1 is presented to show the market share of the selected 10 sample companies:

Table-1 Market Share of Sample Companies of Indian Steel Industry in 2009-10

\begin{tabular}{|l|l|l|}
\hline Rank & Companies & $\begin{array}{l}\text { Market } \\
\text { (Percent) }\end{array}$ \\
\hline 1 & Steel Authority of India (SAIL) & 18.66 \\
\hline 3 & Tata Steel Limited (TSL) & 15.54 \\
\hline 4 & JSW Steel Limited (JSL) & 11.74 \\
\hline 5 & ESSAR Steel Limited (ESL) & 6.87 \\
\hline 6 & JSW Ispat and Steel Limited (JSISL) & 6.63 \\
\hline 7 & Rastriya Ispat Nigam Limited (RINL) & 6.42 \\
\hline 8 & Jindal Steel and Power Limited (JSPL) & 4.76 \\
\hline 9 & Bhushan Steel Limited (BSL) & 3.62 \\
\hline 10 & Llyods Steel Industries Limited (LSIL) & 1.84 \\
\hline & National Steel and Agro Industries Limited (NSAIL) & 1.39 \\
\hline & & \\
\hline
\end{tabular}

\section{Research Methodology}

Discriminant analysis is used in the present study to predict group membership. It is a representative of statistical classification methods. In the present study the companies are categorized into two groups- financially healthy and financially weak. The first step is to determine the coefficients of variables, the second step is to calculate the discriminant score of each case, and the third step is to classify the cases. The linear discriminant function is as follows:

$$
\mathrm{Y}=\mathrm{b}_{0}+\mathrm{b}_{1} \mathrm{x}_{1}+\mathrm{b}_{2} \mathrm{x}_{2}+\mathrm{b}_{3} \mathrm{x}_{3}+\ldots \ldots . .+\mathrm{b}_{\mathrm{n}} \mathrm{x}_{\mathrm{n}}
$$

Where, $\mathrm{Y}$ is the discriminant score, $\mathrm{b}_{0}$ is an estimated constant, $\mathrm{b}_{\mathrm{n}}$ are the estimated coefficients and $\mathrm{x}_{\mathrm{n}}$ are the independent variables. The companies whose scores are more than zero will be categorized as financially 
healthy and vice versa. This analysis is actually used in the study to capture the overall financial scenario of the industry.

\section{Analysis Of Data}

Discriminant analysis is conducted on the selected sample companies to predict group membership and to predict the overall industry condition by distinguishing the sample companies in two groups-financially healthy and financially weak. This technique is used to classify the companies into one of the alternative groups on the basis of set of predictor variables. In the present study, two groups (financially healthy/financially weak) are to be compared on the basis of eight ratios, namely, return on investment (ROI), net profit margin (NPM), current ratio (CR), debt equity ratio (DER), debtor turnover ratio (DTR), creditor turnover ratio (CTR), finished goods turnover ratio (FGTR) and fixed assets turnover ratio (FATR) selected to assess profitability, liquidity, solvency, and efficiency. In the present study stepwise method is used to find out the combination of variables with the intention of presenting the highest prediction accuracy rate and three variables come out to construct the discrimination function. Table-2 shows the group statistics of all ratios under the study.

Table-2

Group Statistics

\begin{tabular}{|c|c|c|c|c|c|}
\hline \multirow{2}{*}{\multicolumn{2}{|c|}{ Performance }} & \multirow{3}{*}{$\begin{array}{l}\text { Mean } \\
11.393764 \\
\end{array}$} & \multirow{3}{*}{$\begin{array}{l}\text { Std. Deviation } \\
4.4640252 \\
\end{array}$} & \multirow{2}{*}{\multicolumn{2}{|c|}{ " Valid N (list wise) }} \\
\hline & & & & & \\
\hline 1 & ROI & & & $\begin{array}{l}\text { Unweighted } \\
6\end{array}$ & $\begin{array}{l}\text { Weighted } \\
6.000\end{array}$ \\
\hline & NPM & 4.470252 & 10.1081892 & 6 & 6.000 \\
\hline & $\mathrm{CR}$ & 1.390182 & .2692539 & 6 & 6.000 \\
\hline & DER & 1.711522 & .6823324 & 6 & 6.000 \\
\hline & DTR & 1.138592 & .2847205 & 6 & 6.000 \\
\hline & CTR & .842777 & .2904337 & 6 & 6.000 \\
\hline & FGTR & .959160 & .2016807 & 6 & 6.000 \\
\hline & FATR & .379793 & .2414081 & 6 & 6.000 \\
\hline \multirow[t]{8}{*}{2} & ROI & 4.671445 & 2.5659885 & 4 & 4.000 \\
\hline & NPM & -8.656807 & 5.5310901 & 4 & 4.000 \\
\hline & $\mathrm{CR}$ & .867722 & .1583631 & 4 & 4.000 \\
\hline & DER & 3.773206 & 2.1236782 & 4 & 4.000 \\
\hline & DTR & 1.019416 & .1360365 & 4 & 4.000 \\
\hline & CTR & .589472 & .0473263 & 4 & 4.000 \\
\hline & FGTR & 1.465492 & .2771965 & 4 & 4.000 \\
\hline & FATR & .070120 & .1530903 & 4 & 4.000 \\
\hline \multirow[t]{8}{*}{ Total } & ROI & 8.704837 & 5.0315171 & 10 & 10.000 \\
\hline & NPM & -.780572 & 10.6260873 & 10 & 10.000 \\
\hline & $\mathrm{CR}$ & 1.181198 & .3484633 & 10 & 10.000 \\
\hline & DER & 2.536196 & 1.7016074 & 10 & 10.000 \\
\hline & DTR & 1.090922 & .2345050 & 10 & 10.000 \\
\hline & CTR & .741455 & .2543992 & 10 & 10.000 \\
\hline & FGTR & 1.161693 & .3414317 & 10 & 10.000 \\
\hline & FATR & .255924 & .2564398 & 10 & 10.000 \\
\hline
\end{tabular}

It is observed from table- 3 that there is significant difference in the mean for ROI, NPM, CR and FGTR for which the $p$-values are $0.027,0.047,0.009,0.010$ which are less than 0.05 , the assumed level of significance. There does not seem to be any significant difference in the means of remaining four variables, namely, DTR, CTR, FATR, and FATR because they possess significant difference as their significance level is more than 0.05 .

Table-3

Tests of Equality of Group Means

\begin{tabular}{|l|l|l|l|l|l|}
\hline Variables & Wilks' Lambda & F & df1 & df2 & Sig. \\
\hline ROI & .524 & 7.267 & 1 & 8 & .027 \\
\hline NPM & .593 & 5.490 & 1 & 8 & .047 \\
\hline CR & .401 & 11.973 & 1 & 8 & .009 \\
\hline DER & .609 & 5.146 & 1 & 8 & .053 \\
\hline DTR & .931 & .592 & 1 & 8 & .464 \\
\hline CTR & .736 & 2.875 & 1 & 8 & .128 \\
\hline FGTR & .414 & 11.345 & 1 & 8 & .010 \\
\hline FATR & .611 & 5.090 & 1 & 8 & .054 \\
\hline
\end{tabular}

Table-4 shows the correlation among the variables and it is observed from the table that no any variable contains more than $|r|>0.75$. It indicates that there is no multicollenearity problem (Chawla and Sondhi, 2011,pp-527).

Table-4 Pooled Within-Groups Matrices

\begin{tabular}{|l|l|l|l|l|l|l|l|l|}
\hline Variables & ROI & NPM & CR & DER & DTR & CTR & FGTR & FATR \\
\hline ROI & 1.000 & .731 & -.527 & .139 & -.046 & -.574 & .154 & -.701 \\
\hline NPM & .731 & 1.000 & -.477 & -.026 & -.574 & -.345 & .121 & -.486 \\
\hline
\end{tabular}




\begin{tabular}{|l|l|l|l|l|l|l|l|l|}
\hline CR & -.527 & -.477 & 1.000 & .526 & .122 & .526 & -.348 & .376 \\
\hline DER & .139 & -.026 & .526 & 1.000 & .273 & .117 & -.557 & -.192 \\
\hline DTR & -.046 & -.574 & .122 & .273 & 1.000 & -.316 & -.199 & -.312 \\
\hline CTR & -.574 & -.345 & .526 & .117 & -.316 & 1.000 & -.218 & .691 \\
\hline FGTR & .154 & .121 & -.348 & -.557 & -.199 & -.218 & 1.000 & .018 \\
\hline FATR & -.701 & -.486 & .376 & -.192 & -.312 & .691 & .018 & 1.000 \\
\hline
\end{tabular}

It is observed from Table-5 that only three variables (FATR, DTR and ROI) retains in the study which helps to discriminate between financially healthy and financially weak steel companies under that study.

Table- $5 \quad$ Variables in the Analysis

\begin{tabular}{|l|l|l|}
\hline Variables & F & Wilks' Lambda \\
\hline ROI & 153.956 & .516 \\
\hline FATR & 148.279 & .498 \\
\hline DTR & 12.837 & .061 \\
\hline
\end{tabular}

The potency of the functions and the discriminating abilities are all assessed by checking the Eigen-values, Wilk's Lambda and Chi-square and its significance level. The function discriminates well and a substantial portion of the variance is explained because it possesses reasonably high Eigen-value (50.646) and low Wilk's Lambda value (0.019). The canonical correlation for the discriminating function is 0.990 , significant at $\rho<0.05$ level (Table-6).

Table-6 Canonical Discriminant Functions

\begin{tabular}{|c|c|c|c|c|c|c|c|c|}
\hline \multicolumn{5}{|c|}{ Eigenvalues } & \multicolumn{4}{|c|}{ Wilks' Lambda } \\
\hline Function & Eigenvalue & $\begin{array}{ll}\% & \text { of } \\
\text { Variance }\end{array}$ & Cumulative \% & $\begin{array}{l}\text { Canonical } \\
\text { Correlation }\end{array}$ & $\begin{array}{l}\text { Wilks' } \\
\text { Lambda }\end{array}$ & $\begin{array}{l}\text { Chi- } \\
\text { square }\end{array}$ & $\mathrm{df}$ & Sig. \\
\hline 1 & $50.646^{\mathrm{a}}$ & 100.0 & 100.0 & .990 & .019 & 25.639 & 3 & .000 \\
\hline
\end{tabular}

a. First 1 canonical discriminant functions were used in the analysis.

It can be concluded that 98.01 percent (square of canonical correlation) of the variance in the discriminating model between financially healthy and weak is due to change in the three predictor variables namely ROI, DTR and FATR. Table-7 shows FATR makes a fairly strong contribution to classifying companies as financially healthy or weak. ROI and DTR also contribute significantly to the model.

Table-7

Standardized and Unstandardized Cannonical Discriminant Function Coefficients

\begin{tabular}{|l|l|l|l|}
\hline Independent Variables & Unstandardized & Standardized & Discriminant Loadings (Rank) \\
\hline FATR & 18.550 & 3.944 & .112 \\
\hline DTR & 6.016 & 1.444 & 0.038 \\
\hline ROI & .972 & 3.754 & .134 \\
\hline Constant & -19.769 & - & \\
\hline
\end{tabular}

From the following table (Table-8) group centroids of both the groups (financially healthy and weak) are obtained.

Table-8 Functions at Group Centroids

\begin{tabular}{|l|l|}
\hline Performance & Function \\
\cline { 2 - 2 } & 1 \\
\hline 1 & 5.197 \\
\hline 2 & -7.796 \\
\hline $\begin{array}{l}\text { Unstandardized canonical discriminant } \\
\text { functions evaluated at group means }\end{array}$ \\
\hline
\end{tabular}

Table-9 shows, the discriminant function is successful in classifying 100 percent of the cases. In the present case the standardized coefficient is zero. Now any company whose discriminant score is more than zero would be classified as a financially healthy company, whereas the one whose score is less than the standardized coefficient would be classified as a financially weak company.

Table-9 Classification Results ${ }^{b, c}$

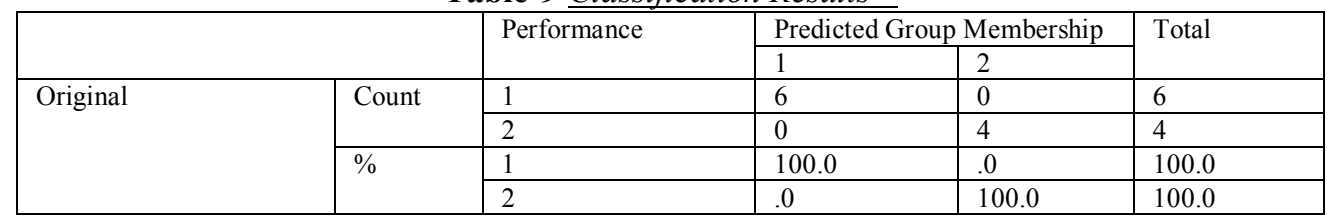




\begin{tabular}{|l|l|l|l|l|l|}
\hline Cross-validated $^{\text {a }}$ & Count & 1 & 6 & 0 & 6 \\
\cline { 2 - 5 } & & 2 & 0 & 4 & 4 \\
\cline { 2 - 5 } & $\%$ & 1 & 100.0 & .0 & 100.0 \\
\cline { 2 - 5 } & 2 & .0 & 100.0 & 100.0 \\
\hline
\end{tabular}

So with the help of discriminating function discrminant scores for the sample companies are computed and presented in Table-10. It shows that mainly six companies namely, TSL, BSL, SAIL, JSPL, NSAIL and RINL shows the discriminant score more than zero so can be classified as a financially healthy but the rest of the four companies ESL, JSL, JSISL and LSIL are classified as financially weak for the entire study period as their discriminant scores are less than zero. The sign of the coefficients associated with all the predictor variables are positive.

Therefore, the study indicates that a high score on ROI, DTR and FATR are likely to classify a company into financially healthy group. Thus, maximization of return on investment and strong collection procedure from debtors with efficient use of fixed assets can make a company financially healthy. In the present case six sample companies holding the market share of 50.39 percent show financial healthiness during the study period.

Table-10

Discriminant Scores of Sample Companies

\begin{tabular}{|l|l|}
\hline Companies & Discriminant Score \\
\hline SAIL & 4.13723 \\
\hline RINL & 4.99932 \\
\hline TSL & 5.23121 \\
\hline ESL & -9.32966 \\
\hline JSL & -6.45610 \\
\hline JSISL & -7.36438 \\
\hline JSPL & 6.06536 \\
\hline BSL & 4.47253 \\
\hline LSIL & -8.03315 \\
\hline NSAIL & 6.27763 \\
\hline
\end{tabular}

\section{Conclusion}

The present study examines the financial distress of Indian steel companies applying discriminant analysis with 15 financial ratios. A strong discriminant function is constructed with selected financial ratios and it is found that three financial ratios namely ROI, DTR and FATR help to discriminate between financially healthy and weak steel companies. It indicates that profitability and efficiency ratios are most important to make the classification. The study shows that a steel company in India may become financially healthy if it implements good debtor management system as well as proper investment policy. Good debtor management facilitates rapid collection of dues from debtors and proper investment policy helps to reinvest the same in the profitable projects to earn a handsome return on investment. On the other hand, fixed assets must be used by the companies in a proper way to boost the sales. Thus, a proper fixed assets management is required to be incorporated by Indian steel companies to increase the sales by using the fixed assets in a suitable way. The empirical result of the study shows that profitability and operational efficiency ratios are helpful in predicting the overall financial health of the companies under the study.

\section{References}

[1]. Altman,E.I. (1968), Financial Ratios, Discriminant Analysis and the Prediction of Corporate Bankruptcy, The Journal of Finance, 23(4):589-609.

[2]. Back,B., Laitinen,T., Sere, K., Wezel, M. (1996), Choosing Bankruptcy Predictors Using Discriminant Analysis, Logit Analysis and Generic Algorithms, Turku Centre for Computer Science, Technical Report No.4, 1-1.

[3]. Bhunia, A. Sarkar, R. (2011), A Study on Financial Distress based on MDA, Journal of Management Research, 3(2):1-11.

[4]. Charitou, A., Nephytou. E., Charalambus, C. (2004), Empirical Evidence for the UK, European Accounting Review, 13(3): 465-497.

[5]. Chawla D. and Sondhi N. (2011), Research Methodology-Concepts and Cases, New Delhi: Vikas Publishing House Pvt. Limited.

[6]. Cleary, S. (1999), "The Relationship between Firm Investment and Financial Status", Journal of Finance, 54(2): 673-692.

[7]. Dichev, I.D. (1998), Is the Risk of Bankruptcy a Systematic Risk? Journal of Finance, 53(3):1131-1147.

[8]. Deloitte (2007). The Framework for the Preparation and Presentation of Financial Statements, International Accounting Standards Board, Accessed 24 June 2007, http://www.svtuition.org/2011/08/corporate-financial-reporting.html

[9]. Dimitras, A.I., Slowinski, R., Susmaga, R., Zopounidis, C. (1999), Business failure prediction using rough sets, European Journal of Operational Research, 114 (1999):263-280.

[10]. Lennox, C. (1999), Identifying Failing Companies: A Revaluation of the Logit, Probit and DA Approaches, http://www.ntu.edu.sg/home/cslennox/JEB99.pdf. Access on August 27, 2013.

[11]. Ohlson, J.A. (1980), Financial Ratios and the Probabilistic Prediction of Bankruptcy, Journal of Accounting Research, 18(1): 109-131.

[12]. Ramanujam, V. Venkatraman, N. Camillus, J. (1986), Multi-objective Assessment of Effectiveness of Strategic Planning: A Discriminant Analysis Approach, Academy of Management Journal, 29(2):347-372.

[13]. Shirata Yoshiko, C. (1999), Financial Ratios as Predictors of Bankruptcy in Japan: An Empirical Research, http://www.citeseerx.ist.psu.edu/viewdoc/download?doi=10.1.1.195.2721\&rep=rep1\&type=pdf. Access on August 27, 2013. 